\title{
Giant aneurysm in medial anterior descending artery: treatment with two endovascular stent grafts on bare metal stent scaffold
}

Duży tętniak środkowego segmentu tętnicy przedniej zstępującej: zabieg angioplastyki wieńcowej przy użyciu dwóch stentgraftów implantowanych w stencie metalowym jako rusztowaniu

\author{
Marek Król, Bartosz Skwarna, Grzegorz Gałuszka, Radosław Szymański, Paweł Buszman \\ $1^{\text {st }}$ Department of Interventional Cardiology and Angiology, American Heart of Poland, Ustroń, Poland
}

Post Kardiol Interw 2011; 7, 2 (24): 173-177 DOI: $10.5114 /$ pwki.2011.23170

\begin{abstract}
We report a case of a 55-year-old male with a history of coronary artery bypass grafts, who presented with symptoms of unstable angina. The coronary angiography revealed a large aneurysm in the medial segment of the anterior descending artery (LAD), chronic total occlusion of circumflex artery (CX), and right coronary artery (RCA), occluded LIMA-LAD, and patent grafts Ao-RCA and Ao-CX. The diameter and length of the aneurysm were $15 \mathrm{~mm}$ and $27 \mathrm{~mm}$, respectively. The length of the aneurysm was longer than any commercially available stent graft. The innovatory method of bare metal stent implantation as a basis of construction and stentin-stent implantation of two stent grafts were performed covering the aneurysm and achieving thrombolysis in myocardial infarction (TIMI) 3 flow in the distal LAD. Unfortunately acute thrombosis was noted $2 \mathrm{~h}$ after the first procedure. Immediately aspiration of the thrombus was successfully performed. The control coronary angiography after 3 days showed TIMI 3 flow in the distal LAD. The patient was discharged home without complications and during 16 months of follow-up he remained asymptomatic. The control coronary angiography performed 16 months after the first procedure revealed patent stent grafts in the LAD without restenosis.
\end{abstract}

Key words: coronary artery aneurysm (CAA), percutaneous coronary intervention ( $\mathrm{PCI})$, stent graft

\section{Streszczenie}

Przedstawiamy opis przypadku 55-letniego pacjenta, który po 13 latach od operacji pomostowania tętnic wieńcowych został przyjęty na I Oddział Kardiologii Inwazyjnej Polsko-Amerykańskich Klinik Serca w Ustroniu z powodu objawów niestabilnej dławicy piersiowej. W wykonanej koronarografii stwierdzono: pień lewej tętnicy wieńcowej (LM) bez zwężeń, drożną tętnicę przednią zstępującą (LAD) z obecnością dużego tętniaka w segmencie środkowym, przewlekle niedrożną gałąź okalającą (Cx), 90-procentowe zwężenie w prawej tętnicy wieńcowej (RCA), niedrożny pomost tętniczy LIMA-LAD oraz drożne pomosty żylne do gałęzi brzeżnej (OM) i RCA. Z uwagi na rozmiary tętniaka i brak stentgraftu o tej długości wykonano nowatorski zabieg angioplastyki wieńcowej z implantacją stentu metalowego jako rusztowania, w którym następnie implantowano dwa stentgrafty, uzyskując zamknięcie jamy tętniaka. Ze względu na wystąpienie ostrej zakrzepicy w implantowanych stentgraftach wykonano skuteczny zabieg trombektomii aspiracyjnej z podaniem inhibitora GP IIb/IIla. W wykonanej kontrolnej koronarografii po 3 dniach zaobserwowano prawidłowy przepływ w naczyniu środkowym - TIMI 3. Obecnie pacjent nie odczuwa żadnych dolegliwości, a w koronarografii wykonanej po 16 mies. stwierdzono drożne stentgrafty bez cech restenozy.

Słowa kluczowe: tętniak tętnicy wieńcowej, angioplastyka wieńcowa, stentgraft

\section{Introduction}

Ischaemic heart disease is a result of blood flow impairment in coronary arteries, usually caused by coronary artery stenosis. Another issue observed in $1.5-5 \%$ of studies is the presence of coronary artery aneurysms (CAA), abnormal dilatation of a segment of the coronary artery [1]. The diagnostic criteria for aneurysm is arterial lumen dilation greater than 1.5 times its maximum diameter [2]. Dilated artery sections covering over $50 \%$ of the artery length are called ectasias [2].

Corresponding author/Adres do korespondencji:

Bartosz Skwarna, $1^{\text {st }}$ Department of Interventional Cardiology and Angiology, American Heart of Poland, Ustroń, Poland,

e-mail: skwarna@poczta.onet.pl

Praca wpłynęła: 14.01.2011, wersja poprawiona: 22.05.2011, przyjęta do druku: 25.05.2011. 
Aneurysms may be congenital anomalies (prevalent in patients under 33 years of age) or secondary anomalies (prevalent in patients above age 56) [3]. Aneurysm formation is mainly caused by atherosclerosis and Kawasaki disease, less often by polyarteritis nodosa, connective tissue diseases (Marfan and Ehlers-Danlos syndromes), systemic diseases (lupus erythematosus), infectious diseases (syphilis and mycotic infections), metastases, polycystic kidney disease, mechanical trauma, and percutaneous coronary intervention $(\mathrm{PCl})$ complications $[4,5]$.

Aneurysms are most commonly located in the right coronary artery (RCA), then in the left anterior descending artery (LAD) and the circumflex artery (CX), while left main coronary artery (LMCA) dilation is observed least frequently [6]. The course is asymptomatic in most patients, although some show symptoms of coronary artery disease.

According to physical laws governing blood flow, e.g. Bernoulli's principle, in the aneurysmal lumen a slowing down of blood flow and blood pressure elevation occurs, which in combination with the weakened aneurysm wall causes a substantial risk of aneurysm rupture and cardiac tamponade. Additionally, the slowed down blood flow contributes to formation of clots and peripheral embolisms, leading to heart ischaemic symptoms including myocardial infarction [6]. Development of fistulas in heart cavities, aorta, or pulmonary artery was observed in some patients $[6,7]$.

There are no established standards of management for CAA patients. Conservative treatment may be used, with antiplatelet drugs, anticoagulants, and anti-inflammatory drugs in cases with confirmed inflammatory aetiology. Sur-

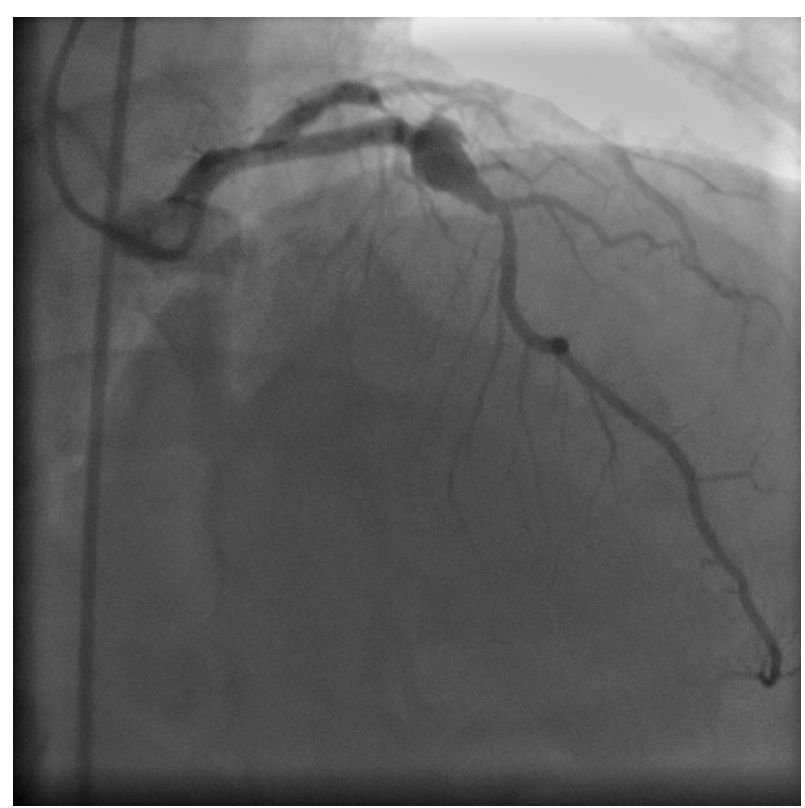

Fig. 1. Aneurysm of the medial segment of the anterior descending artery

Ryc. 1. Tętniak medialnego odcinka tętnicy przedniej zstępujacej gical treatment consists of stent grafts and coronary artery bypass grafts (CABG) with aneurysm cavity ligation $[6,7]$.

\section{Case report}

We report a case of a 55-year old male admitted on 28 August 2009 with symptoms of unstable angina (UA) in Canadian Cardiology Society (CCS) class IV and Braunwald class III B. Medical history revealed status post two myocardial infarctions in 1994 and 1995. In 1995 the patient underwent CABG in a clinic in Germany (no medical records available). For many years the patient has been treated for hypertension and hypercholesterolaemia.

Performed coronarography revealed: no stenosis in the left main artery (LMA), a patent LAD with a large aneurysm present in its medial segment (fig. 1), a chronically obstructed Cx, a 90\% stenosed RCA, an obstructed LIMA-LAD graft, and patent venous grafts to obtuse marginal artery (OM) and RCA.

The patient was qualified for coronary angioplasty with stent graft implantation in the medial segment of the LAD.

A guidewire was inserted into the aneurysm cavity and a precise measurement of the aneurysm length was made (via QCA and comparing with the inserted balloon catheter); examination showed that the aneurysm measured $15 \times$ $\times 27 \mathrm{~mm}$ and was longer than any post market available stent grafts (the longest available stent grafts are the $26 \mathrm{~mm}$ long Abbott Vascular's JOSTENT Coronary Stent Graft and ProCardia Medical's Direct Stent Stent-Graft). A decision was made to perform angioplasty by implanting a single long bare metal stent which would serve as a scaffold for two stent grafts consecutively implanted in its lumen.

The proximal end of the implanted M-L ZETA $3.0 \times 33 \mathrm{~mm}$ stent covered the vessel before the aneurysm and its distal end reached the vessel on the other side of the aneurysm (figs. 2, 3). Subsequently, a Graftmaster $3.0 \times$ $\times 19 \mathrm{~mm}$ stent graft was implanted in the distal part of the aneurysm (figs. 3, 4), and a Graftmaster $3.5 \times 19 \mathrm{~mm}$ stent graft in its proximal part (fig. 5, 6); both stent grafts were post-dilatated. Eventually, closure of the aneurysm cavity was achieved and thrombolysis in myocardial infarction (TIMI) 3 flow to the peripheral LAD (fig. 7).

Roughly $2 \mathrm{~h}$ after the procedure the patient reported chest pain. Electrocardiogram showed ST elevation in anterior leads and control coronarography revealed the presence of a clot within the implanted stents with a peripheral TIMI 2 flow. A guidewire was inserted and the clot was aspirated with an Expert AP catheter while the patient was given single bolus and continuous infusion of eptifibatide intravenously. Thrombolysis in myocardial infarction 3 flow was achieved.

Lab tests revealed significant elevation of creatine phosphokinase (CPK) values, from $56 \mathrm{IU} / \mathrm{l}$ initially, to a maximum CPK 1070 IU/I and CPK-MB: 94 IU/I on day 2, and then renormalization on day 4 .

Control coronarography performed on day 6 revealed normal flow in the LAD (figs. 8 A, B). Echocardiography 


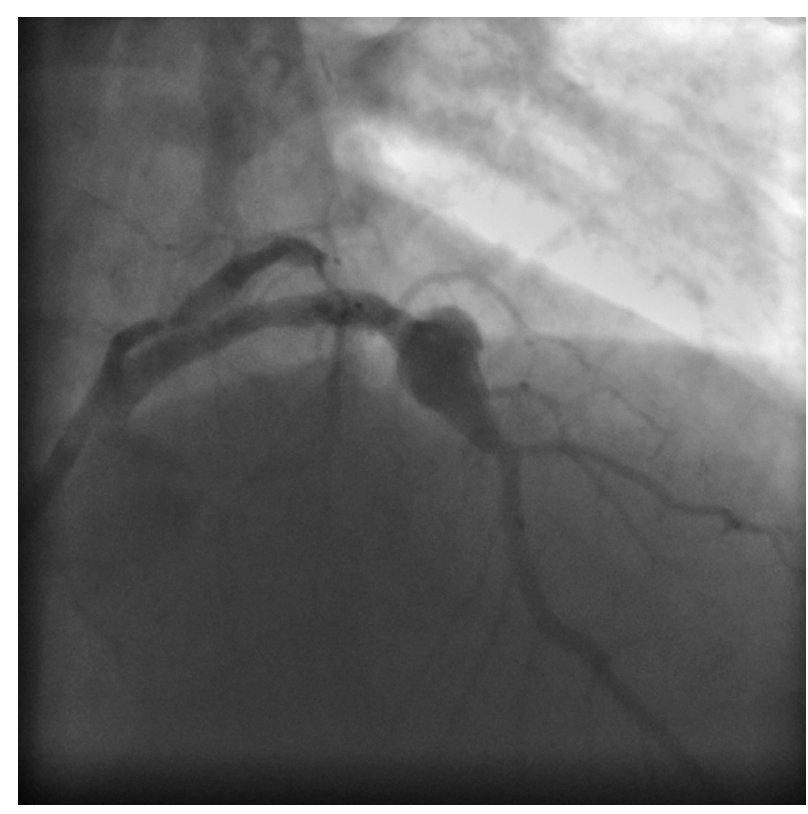

Fig. 2. Positioning of the classic bare metal stent inside the aneurysm

Ryc. 2. Pozycjonowanie klasycznego stentu metalowego w obrębie tętniaka

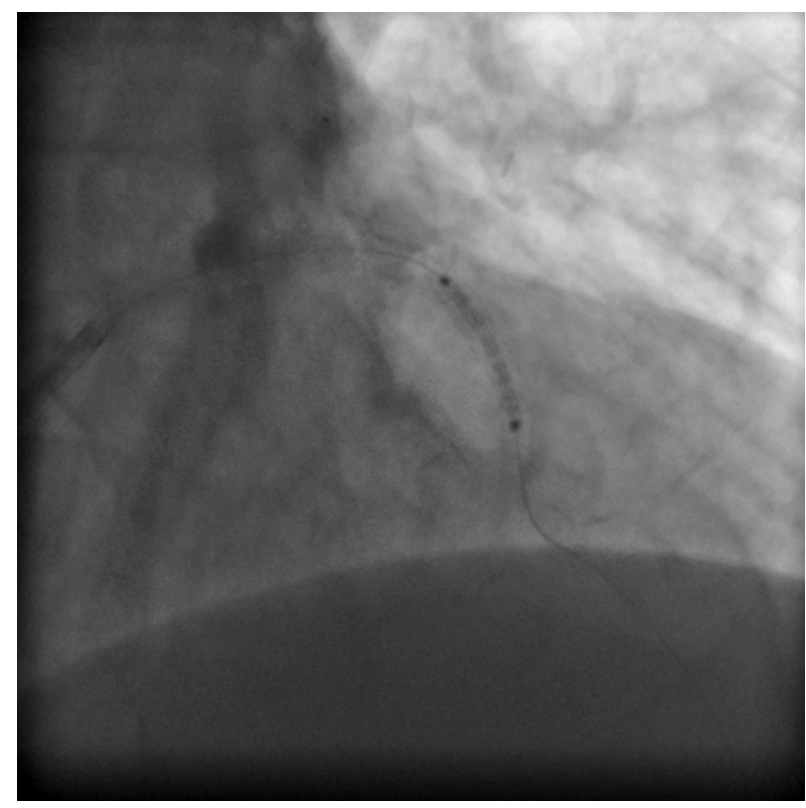

Fig. 4. Positioning of the first stent graft Ryc. 4. Pozycjonowanie stentgraftu $n r 1$

performed before the first procedure revealed apical hypokinesis, basal inferior segment akinesis, and basal inferoseptal akinesis with left ventricular ejection fraction (LVEF) $45 \%$.

A follow-up examination on day 5 revealed apical anterior hypokinesis with LVEF 40\% (contractility of remaining segments as in previous examination).

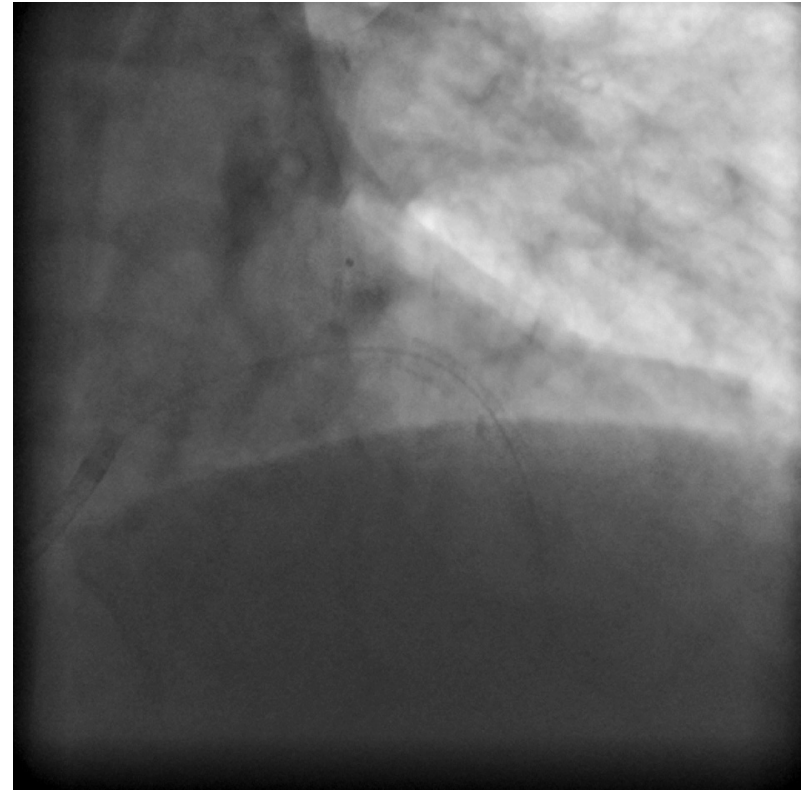

Fig. 3. Implanted classic bare metal stent Ryc. 3. Implantowany klasyczny stent metalowy

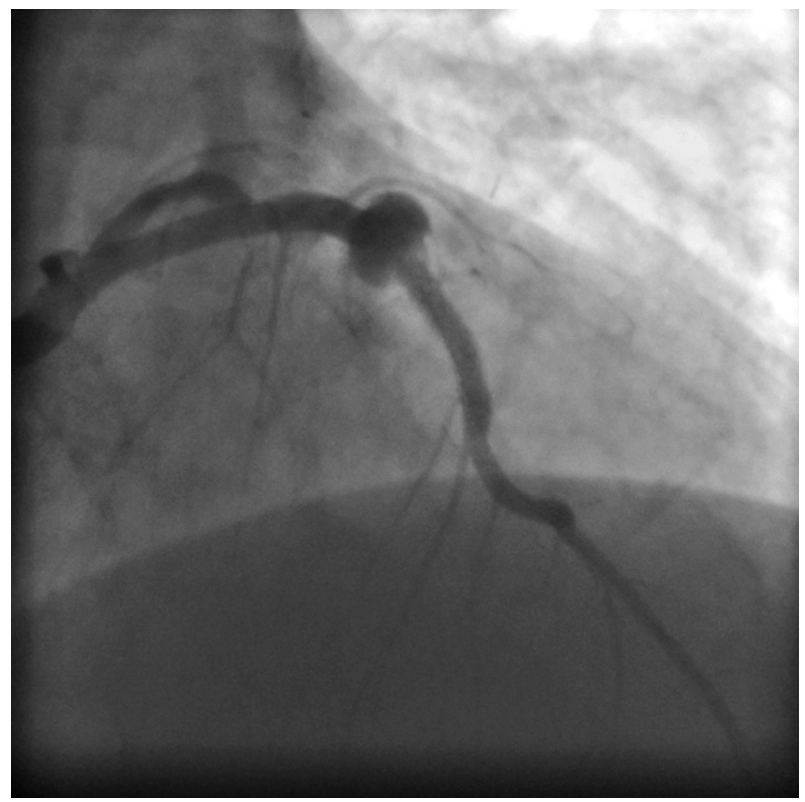

Fig. 5. First stent graft after implantation Ryc. 5. Implantowany stentgraft $n r 1$

The patient was discharged 7 days after the procedure. Currently the patient is monitored at the Cardiology Outpatient Clinic, feels well, reports activity limitations in CCS classes I/II and New York Heart Association (NYHA) class I. A control angiography performed on 8 January 2011 revealed patent stent grafts in the LAD with no restenosis. 


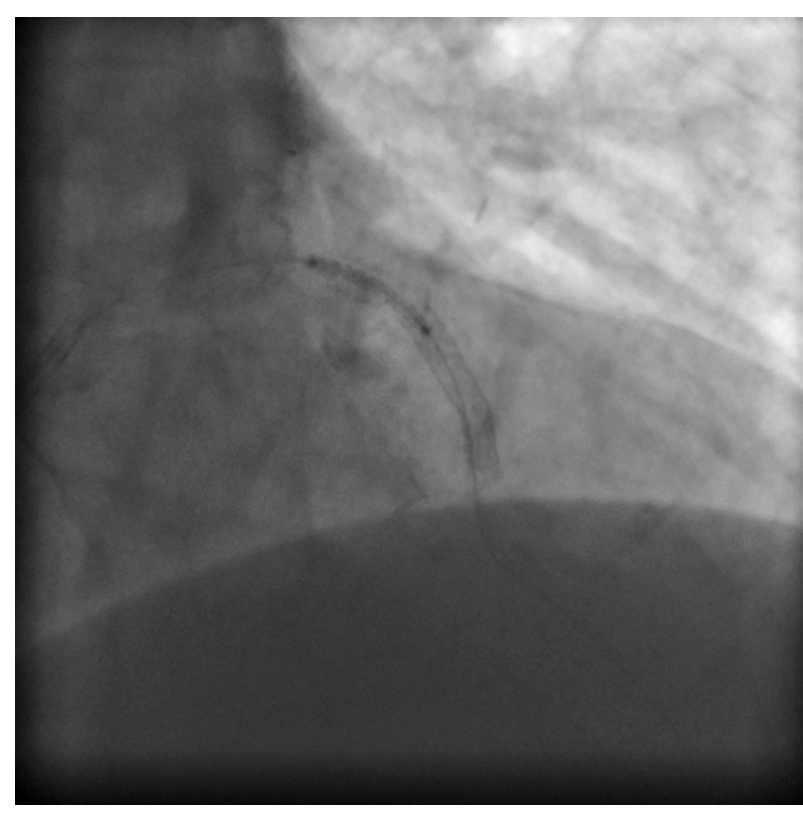

Fig. 6. Positioning of the second stent graft Ryc. 6. Pozycjonowanie stentgraftu nr 2

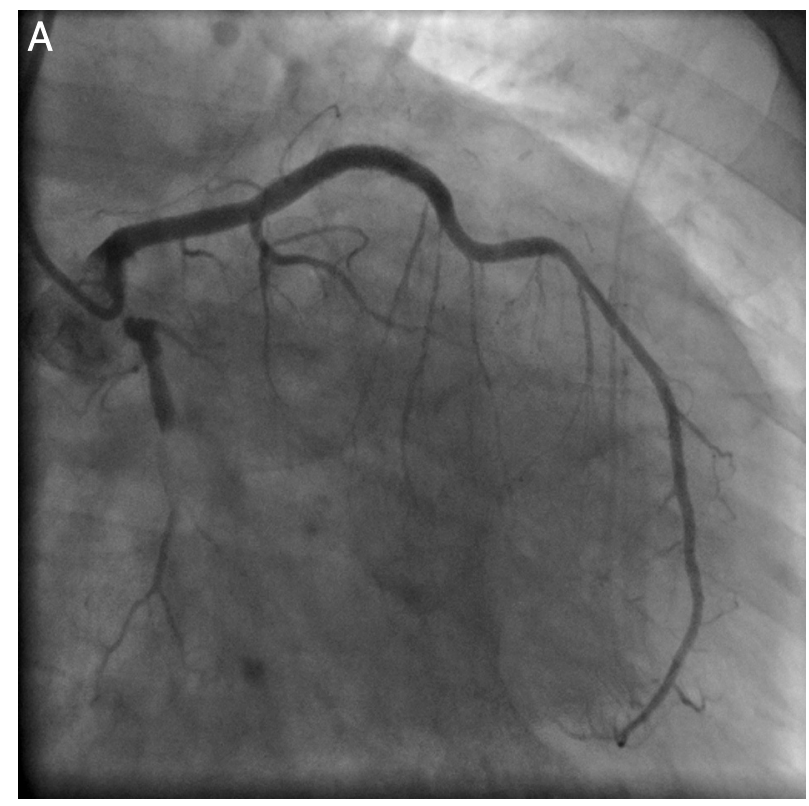

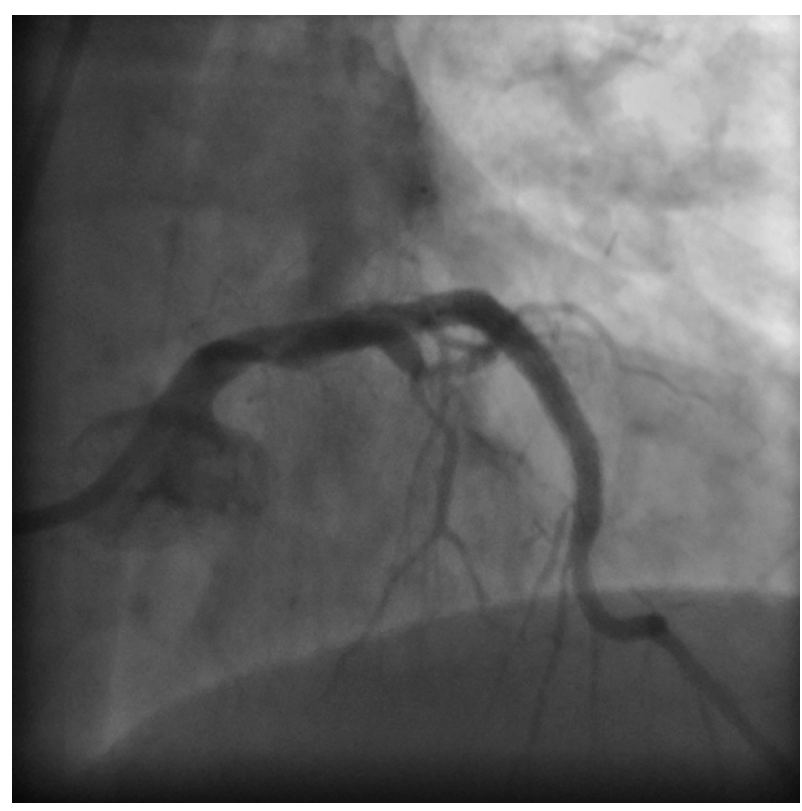

Fig. 7. Left anterior descending artery with two stent grafts implanted inside a classic bare metal stent Ryc. 7. Tętnica przednia zstępująca z implantowanymi dwoma stentgraftami w obrębie klasycznego stentu metalowego

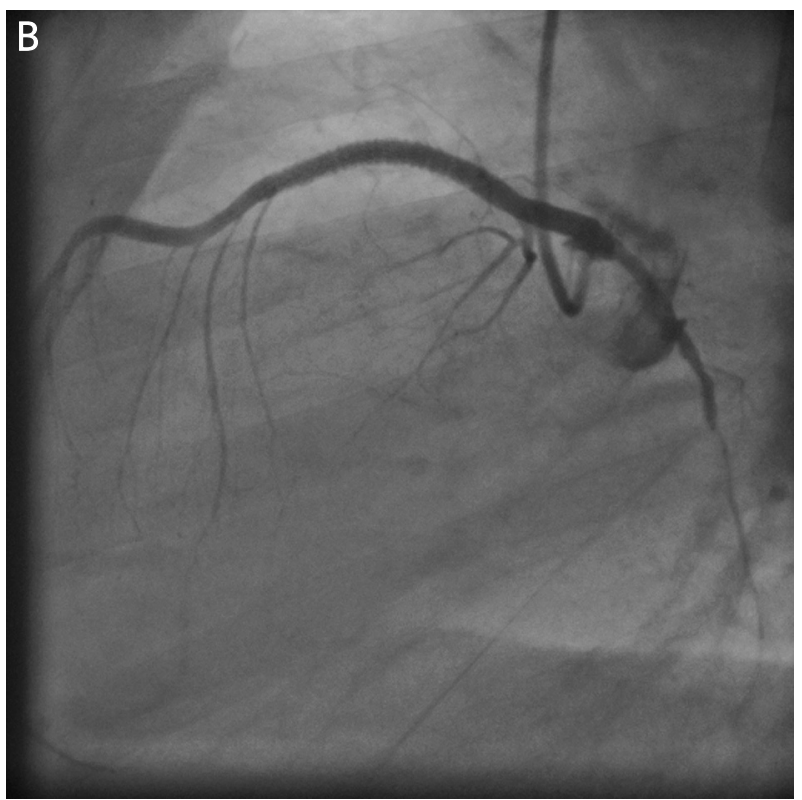

Fig. 8 A, B. Control coronary angiography at day 6 of hospitalization

Ryc. 8 A, B. Kontrolna koronarografia w 6. dobie pobytu

\section{Discussion}

The patient's age and history indicate atherosclerosis as the most likely cause of CAA. At present, as there are no established standards of management for CAA patients, conservative therapy, percutaneous treatment, and cardiac surgery are to be considered $[6,7]$.
In the presented case, large dimensions of the aneurysm increase the probability of rupture. Additionally, the slow blood flow in its lumen increases the risk of peripheral embolism. Because of the risk associated with a cardiac reoperation, the patient was qualified for percutaneous treatment. 
The innovative technique of using bare metal stent (BMS) as a scaffold for the implantation of two stent grafts proved effective and technically easy to perform. Acute thrombosis within the stents $2 \mathrm{~h}$ after implantation is a reason for substantial concern and attention. Stent graft implantation bears a greater risk of acute thrombosis than implantation of BMS or drug-eluting stents (DES). Use of clopidogrel at an appropriately early stage is extremely important for these patients.

The patient received standard antiplatelet and anticoagulant treatment and also a loading dose of $600 \mathrm{mg}$ of clopidogrel immediately before the procedure. Although the used treatment did not protect the patient from acute thrombosis, after the aspiration of thrombus and administration of GP IIb/IIla receptor blocker the blood flow in the artery was restored and no relapse of the vessel occlusion was observed. A very good angiographic effect achieved and confirmed by control angiographies on day 6 and after 16 months indicates a correctly performed coronary angioplasty.

We estimate that in patients undergoing stent graft implantation a loading clopidogrel dose should be used at least $24 \mathrm{~h}$ before the procedure, while use of GP IIb/IIla receptor blocker and protracted anticoagulant treatment is indicated for emergencies.
The patient remains under constant regular control of our outpatient clinic. Presently, he reports symptoms in CCS class I/II. ASA, statin, $\beta$-blocker and convertase enzyme (ACE) inhibitor were maintained in treatment. He follows dietary restrictions and his present cholesterol values reached the desired level for high-risk group patients.

\section{References}

1. Nichols L, Lagana S, Parwani A. Coronary artery aneurysm: a review and hypothesis regarding etiology. Arch Pathol Lab Med 2008; 132: 823-828.

2. Swaye PS, Fisher LD, Litwon P, et al. Aneurysmal coronary artery disease. Circulation 1983; 67: 134-138.

3. Lenihan DJ, Zeman HS, Collins GJ. Left main coronary artery aneurysym in association with severe atherosclerosis: a case report and review of the literature. Cathet Cardiovasc Diagn 1991; 23: 28-31.

4 Markis JE, Joffe CD, Cohn PF, et al. Clinical significance of coronary arteria ectasia. Am J Cardiol 1976; 37: 217-222.

5. Wong CK, Cheng CH, Lau CP, et al. Asymptomatic congenital coronary artery aneurysm in adulthood. Eur Heart J 1989; 10: 947-949.

6. Ramappa P, Kottman A, Kuivaniemi H, et al. Coronary artery ectasia - is it time for reappraisal? Clin Cardiol 2007; 30: 214-217.

7. Pahlavan PS, Niroomand F. Coronary artery aneurysym: a review. Clin Cardiol 2006; 29: 439-443. 